\title{
To Conscience First, and to the Pope (Long) Afterwards? British Catholics and Their Attitudes Towards Morality and Structural Issues Concerning the Catholic Church
}

\section{Ben Clements $^{1}\left[\right.$. Stephen Bullivant ${ }^{2}$}

Received: 30 September 2020 / Accepted: 18 March 2021 / Published online: 24 April 2021

(c) The Author(s) 2021

\begin{abstract}
Background The attitudes of Catholics in Britain have undergone significant liberalisation on social moral issues across recent decades, whilst the reputation of the Catholic Church has suffered due to public opposition to its traditional teachings on such issues. But there has been comparatively little recent investigation into British Catholics' views on these debates using surveys aimed at this religious community. Purpose This article examines the sources of attitudinal heterogeneity amongst Catholics in Britain on core debates affecting the Catholic Church. The aims are to examine, firstly, which groups within the British Catholic Community are more likely to conform to or to dissent from the Church's teachings and, secondly, whether the socio-demographic and religious correlates of attitudes vary across different types of issue.

Methods This article uses a new, nationally representative survey of Catholic adults in Britain $(n=1823)$. The survey is used to examine the sources of variation in Catholics' attitudes towards a range of issues relating to the Roman Catholic Church. These issues relate to the priesthood, personal morality, and sinful behaviours. OLS models are used to assesses the relative impact of socio-demographic, religious socialisation, and religious commitment variables.

Results The findings show that women are consistently more liberal in their views than men. Greater religious commitment is always associated with support for the traditional teachings of the Church.

Conclusions and Implications Exploring the sources of attitudinal heterogeneity among Catholics, we provide new insights into the internal dynamics of 'Britain's largest minority'. We conclude by discussing the potential effects of increasing 'nonversion' for interpreting religious statistics — a topic of relevance beyond the denominational and geographical confines of this study's explicit focus.
\end{abstract}

Keywords Britain · Catholics · Roman Catholic Church · Religious commitment · Social moral issues $\cdot$ Structural issues 


\section{Introduction}

How do Catholics in Britain relate to the teaching authority of the Roman Catholic Church? Which groups within the Catholic community are more or less likely to hold views that are consistent with, or opposed to, the long-held teachings of the Church? These are important questions for scholarly inquiry for a number of reasons. Firstly, recent research has shown how the view of Catholics in Britain on social moral issues have undergone a process of liberalisation across recent decades, encompassing debates over abortion, assisted suicide, and samesex relations (Clements 2014a, 2015) - giving heed, in the famous words (if not meaning) of St John Henry Newman, the nineteenth century English convert from Anglicanism whom the Church canonized in 2019, 'to Conscience first, and to the Pope afterwards' (1875, p. 86). Second, the public image of the Catholic Church has been affected through perceptions of its unchanging stance on these moral issues, part of a more general decline in the standing of church and clergy in British society. As Field has observed: 'the Catholic Church's reputation has undoubtedly diminished, largely in consequence of negative reactions to the Church's conservative social ethics' (2014, p. 203). Recent polling has shown majorities of the British public took the view that the Catholic Church should change its teachings on issues such as abortion, homosexuality, celibacy, and women priests (Populus 2010). In recent years, the Church's reputation with the British public in general and the Catholic community specifically has also been severely affected by the child sex abuse scandal (Field 2014, p. 212). Moreover, interventions by Catholic bishops in public debates have engendered mixed reactions amongst the public in general and Catholics in particular. Asked about religious leaders' intervening on personal morality issues, 54\% of Catholics (and $40 \%$ of the general public) supported their right to get involved while $30 \%$ of Catholics (44\% of the general public) opposed it (YouGov 2015). In relation to taking note of these interventions, $41 \%$ of Catholics did pay attention while $45 \%$ said they did not (YouGov 2015).

Thirdly, broader social and demographic change have affected the Catholic Church and the wider faith community in Britain. Catholics currently account for $7 \%$ of the British adult population (approximately 3.6 million people). This makes them Britain's second-largest religious group by self-identification, after Anglicans at $12 \%$ (an identification which has steadily declined over recent decades from a much higher level), and with Muslims below them at 6\% (Voas and Bruce 2019). In terms of religious involvement, Catholics have typically attended church at higher rates than Anglicans but at broadly similar levels to other Christians, although over recent decades their level of regular churchgoing has changed, with fewer frequent attenders and more infrequent attenders (Clements 2020). Even so, on the most recently available data, Catholicism is the dominant religious group in terms of attendance at services across Britain as a whole, even if one counts each nation's main Anglican/Episcopalian body (i.e., the Church of England, the Church in Wales, and the Scottish Episcopal Church) as a single denomination (Kinnear, forthcoming). Historically, the broader economic disadvantages and 
socio-political discrimination they suffered as a migrant community - with many Catholics having an Irish heritage-meant that that their 'natural party' was Labour, on the left of British politics (Bruce 2012, pp. 23-24). However, that partisan advantage for Labour-the party-denomination link-has appeared to weaken over time (Clements 2017). The Catholic community nowadays exhibits a more pluralist fabric in relation to national origins and ethnicity given the recent significant inflows of Catholic migrants coming from Eastern Europe and elsewhere (e.g., the Philippines, India).

The last major academic investigation of the Catholic community (in England and Wales, not Britain) was conducted in late-1970s (Hornsby-Smith 1987; HornsbySmith and Turcan 1981; Hornsby-Smith et al. 1982; Hornsby-Smith and Lee 1979). It found that the 'distinctive subculture' of the post-war Catholic community was evolving and dissolving in complex ways, due both to processes of social change, not least the growing embourgeoisement of a hitherto predominantly working-class community, and seminal developments within the Church, primarily the Second Vatican Council (Hornsby-Smith 1987). This research also demonstrated growing heterogeneity in Catholics' religious beliefs, practices, attitudes, including how they related to the authority of the Catholic Church. Catholics gave less credence and thus accorded less legitimacy to the pronouncements of clerical authority on issues relating to morality, and also wanted greater dialogue and accountability within the structures of the Catholic Church (Hornsby-Smith 1999, pp. 293-294).

Two decades on from this major study in the late-1970s, one of the academic investigators could observe that 'there have been no major studies of English Catholics since Roman Catholic Opinion' (Hornsby-Smith 1999, p. 6). A further two decades on and there has been a recent emergence of survey-based research on the Catholic community in Britain. Firstly, some studies have relied on using Catholic subsamples from general surveys to analyse contemporary aspects of the community (Bullivant 2016a, 2016b, 2019) or to document changes in religious engagement and socio-political attitudes over time (Clements 2015, 2016a, b). Second, there has been analysis of Catholics' attitudes on social morality issues in particular, using one-off opinion polls of Catholics (Clements 2014a, b; Woodhead 2013a, b). However, there has been no wide-ranging academic study of, let alone a recurrent survey series tracking, the opinions of the Catholic community in Britain. In comparison, D'Antonio and academic collaborators have surveyed the U.S. Catholic population on six occasions between 1987 and 2017 (D'Antonio 2017; D'Antonio et al. 1989, 1996, 2001, 2007, 2013). Other large-scale surveys have been carried out by organisations such as the Pew Research Center (2015), supplemented by studies based on Catholic subsamples within national surveys, such as the General Social Survey (Greeley 1990; Bullivant 2019) and the National Study of Youth and Religion (Smith et al. 2014).

To address this gap in scholarly knowledge, this study focuses on examining how Catholics in Britain relate to the teaching authority of the Church, using a new survey which offers a rich set of measures pertaining to socio-demographic circumstances, religious socialisation, and personal engagement with faith. Specifically, it examines: (1) which groups within the Catholic Community are more likely to conform to, or to dissent from, the Church's teachings; and (2) whether 
socio-demographic and religious correlates of attitudes differ across the type of issue. The analyses provided important insights into the sources of attitudinal heterogeneity on key areas of internal debate for the Catholic Church: firstly, social morality issues relating to relationships and 'sanctity of life' issues; secondly, traditions and practices relating to the priesthood and confirmation (D'Antonio et al. 2011, p. 273). More widely, the study also contributes to the analysis of how 'largescale secularising trends have been (and are being) mediated differently within different British Christian groupings' (Bullivant 2016b, p. 195).

\section{Existing Research into the Attitudes of Catholics and the Catholic Church's Teaching Authority}

What insights have been provided from previous research into the attitudes of Catholics in Britain? Analysis of a seminal survey of the English Catholic community from 1978 found that regular attenders at Mass 'conformed much more closely to the official norms of the Church' (Hornsby-Smith 1991, p. 165). In terms of age, this study found that 'Catholics are more likely to be critical of the institutional Church or of its authorities or of its official teachings or regulations the younger they are' (Hornsby-Smith and Lee 1979, pp. 130-131). The limited recent research into the attitudes of Catholics in Britain, using denomination-specific surveys, has focused on a narrower set of social-morality issues (Clements 2014a, b). These studies have shown that Catholic women were more liberal than men in their views of abortion and homosexual relations, as were younger people and infrequent attenders at Mass (Clements 2014a). Another study of British Catholics' attitudes towards 'sanctityof-life' issues-assisted suicide and abortion - found that women and older people were more likely to support the current legal situation whereby assisted suicide is illegal, while measures of religious commitment—regular Mass attendance, belief in God, and reading scripture-also predicted support for the status quo (Clements 2014b). The same study showed that, when asked specifically about different options regarding the time limits contained within the laws governing abortion, older people and those showing greater religious commitment were less supportive of retaining or increasing the time period allowed compared to banning them altogether; those from a White British ethnic background and in higher socio-economic locations were more supportive (Clements 2014b). Comparing the options of reducing the time limit allowed versus banning abortion altogether, women and older people were less in favour of the former, as were those who attended Mass more regularly, and those who believed in God or read scripture (Clements 2014b). Conversely, those in higher socio-economic groups and from a White British ethnic background were more supportive (Clements 2014b).

While this limited research has provided some insights into the contemporary sources of attitudinal variation amongst Catholics in Britain, it has only been able to consider limited aspects of religious commitment-relating to behaving and believing - and has not been able the examine the role of the religious socialisation of Catholics-which could be a formative influence on how individuals develop within their faith—nor how salient the Roman Catholic Church is for them personally. 
Moreover, moving beyond these moral debates, recent research into British Catholics provides little insight into their attitudes on structural issues within the Catholic Church - the sources of attitudinal heterogeneity on debates relating to the priesthood and women's roles in particular.

In contrast, research into Catholics' attitudes in the U.S., both one-off studies and recurrent surveys, has generated a wealth of insights into the correlates of their attitudes on a range of issues. These include social morality issues (Mulligan 2006; Jelen 2005; Smith 2005; Bjarnason and Welch 2004; Mockabee et al. 2001; Perl and McClintock 2001) as well as structural issues within the Church (Berrelleza and Zagano 2019; Knoll and Bolin 2018). More encompassing studies have focused on both types of issue (Gray and Gautier 2018; Pew Research Center 2015; D’Antonio et al. 2001, 2007, 2013; Baggett 2008).

Another strand of research on U.S. Catholics has provided more focused analysis of the positions taken in particular moral debates, particularly on 'sanctity-of-life' issues such as abortion and the death penalty, as well as same-sex equality issues. This research has also underlined the role of demographic factors, religious commitment, and political attitudes in structuring Catholic attitudes on these debates. In terms of attitudes to abortion, opposition has tended to be found amongst older people, Hispanic Catholics, (Mulligan 2006; Mockabee et al. 2001), while higher levels of education tend to be associated with more pro-choice views on the debate (Smith 2005) and with more liberal attitudes on issues concerning same-sex rights (Smith 2005). On the death penalty, support has tended to be concentrated amongst men, White Catholics, and those with lower levels of education (Jelen 2005; Smith 2005; Bjarnason and Welch 2004; Perl and McClintock 2001). In general, more frequent attendance at Mass and greater religiosity as expressed through other aspects of commitment have been found to be associated with opposition to abortion (Mulligan 2006; Jelen 2005; Smith 2005; Mockabee et al. 2001) and to same-sex relationships (Smith 2005), but to underpin opposition to the death penalty (Mulligan 2006; Jelen 2005; Smith 2005; Bjarnason and Welch 2004). In terms of political attitudes, studies have generally shown that Republicans and those with conservative ideology are more likely to oppose abortion (Mulligan 2006; Jelen 2005; Smith 2005; Perl and McClintock 2001), more likely to be in favour of the death penalty (Jelen 2005; Smith 2005; Bjarnason and Welch 2004; Perl and McClintock 2001), and to have traditional views on same-sex issues (Smith 2005).

Utilising a new survey enabling in-depth and robust analysis of attitudes, this study addresses the current limitations in the scholarly literature regarding Catholics in Britain in three important respects. First, the thematic scope of the study encompasses both social morality issues and structural issues relevant to ongoing debates within the Catholic Church in Britain (and the separate bishops' conferences governing (1) Scotland and (2) England and Wales). Second, the survey builds on insights from existing survey-based scholarship on Catholics in the U.S. by examining the multi-faceted nature of British Catholics' religious commitment, capturing the complex ways in which this may affect their attitudes different issues (Rinaman et al. 2009; Mockabee et al. 2001). This study's approach to measuring religious commitment encompasses two particular aspects which are important for Catholics. Firstly, salience: the importance of the Church in the lives of Catholics. 
Secondly, behaviour: the nature and extent of Catholics' participation within the Church (D'Antonio et al. 1996, p. 76). It also means that the key facets of believing and behaving will also be addressed in the analysis (Wald and Smidt 1993), given that our entire sample 'belong' to (that is, they self-identify with) the Catholic faith. Third, the study takes the approach of examining the diverse demographic underpinnings of Catholics' attitudes that have been demonstrated in existing research from the U.S., which established that significant sources of group variation in views of Church authority include gender, ethnicity, generational group, and level of commitment to the Church (D'Antonio et al. 2001, 2007, 2013). Demographic 'priors' are assumed to influence how Catholics identify with and the commitment they show to, their faith, which in turn can affect their attitudes on a range of issues (D'Antonio et al. 2007, p. 10). This approach is followed in terms of the different sets of explanatory factors assessed in relation to British Catholics' views on moral and structural issues.

\section{Methods}

The new survey allows in-depth assessment of the contemporary sources of attitudinal heterogeneity on social and structural issues amongst British Catholics-in terms of demographic traits, religious upbringing and schooling, commitment to their faith and Church, and their political attitudes. This survey represents the first major, wide-ranging academic-led study of the Catholic community in Britain since the late-1970s, when a seminal study of the opinions of Catholics in England and Wales was undertaken (Hornsby-Smith and Lee 1979; Hornsby-Smith 1987, 1991).

The survey of adult Catholics (aged 18 and over) living in Britain (England, Wales, and Scotland) was administered online by the survey research organisation Savanta ComRes. Savanta ComRes is a member of the British Polling Council and has a Faith Research Centre with expertise in undertaking surveys on religious issues. For its online surveys, it has proprietary panels in the UK and U.S., each comprising several hundred thousand active members. Research in the U.S. has used online surveys for surveying the Catholic community (D'Antonio 2017; D'Antonio et al. 2013) and recent research in Britain has used online surveys to research the attitudes of minority religious populations, including Catholics (Clements 2014a 2014b; Woodhead 2013a, 2013b) and Jews (Barclay et al. 2019).

The fieldwork was undertaken between 21st October and 7th November 2019. Catholic respondents were first identified by use of a standard screening question, used in existing research, to ensure only individuals who currently identified as Catholic were sampled (D'Antonio et al. 2013, p. 155). The wording (taken from the long-running British Social Attitudes (BSA) survey question on religious affiliation) was as follows: 'Do you regard yourself as belonging to any particular religion? If yes, which?'. The interview was immediately terminated for those respondents who self-identified with another religion or who did not self-identity with any religion. The total $n$ for the survey sample was 1823 . Post-fieldwork, the sample was weighted to make it nationally representative of Catholic adults in Britain (in terms of age, sex, and region; calibrated according to Catholic subsamples in pooled data 
Table 1 Distribution of opinion (\%)—-the priesthood and personal morality

\begin{tabular}{llll}
\hline Issue & Should & Should not & Don't know \\
\hline Priesthood & & & \\
Allow priests to get married & 68 & 18 & 14 \\
Allow already-married men to become priests & 68 & 17 & 15 \\
Allow women to become priests & 66 & 21 & 14 \\
$\begin{array}{l}\text { Personal morality } \\
\text { Allow Catholics to use birth control }\end{array}$ & 82 & 10 & 8 \\
$\begin{array}{l}\text { Recognise the marriage of same-sex couples } \\
\text { Allow divorced Catholics who remarry without get- }\end{array}$ & 55 & 29 & 16 \\
$\quad$ ting an annulment to receive communion & 67 & 16 & 17 \\
Allow Catholics who are living with a romantic part- & 76 & 11 & 13 \\
ner without being married to receive communion & & & \\
\hline
\end{tabular}

Percentages sum across each row but may not total 100 due to rounding

from recent waves of the BSA survey). The study forms part of a project ('Roman Catholics in Britain: Faith, Society and Politics') funded by a grant from the Arts and Humanities Research Council (AH/S003258/1), United Kingdom.

\section{Dependent Variables}

Catholics' engagement with the Church's moral authority can be usefully separated into two types of issue:

The church's teaching authority covers a broad range of moral and structural issues: some of the moral issues concern family and human sexuality; others concern war and capital punishment; still others concern social justice for the poor, aged and persons otherwise neglected in human society. Structural issues have to do with the church's hierarchic governing structure and access to roles within it (D’Antonio et al. 2011, p. 273).

To examine Catholics' views on both moral and structural issues, the survey featured two sets of questions taken from the Pew Research Center's (2015) Survey of U.S. Catholics and Family Life, which were adapted for use in the British context. The first dependent variable is based on a set of questions asking about the desirability of reforms within the Catholic Church. In accord with the distinction noted above, these items covered issues of morality (allow Catholics to use birth control; recognise marriages of same-sex couples; allow divorced Catholics who remarry without getting an annulment to receive communion; allow Catholics who are living with a romantic partner without being married to receive communion) and structural issues concerning access to the priesthood within the Catholic Church (allow priests to get married - this item was added, not featuring in the Pew 2015 survey; allow already-married men to become priests; allow women to become priests). The response options for all of these questions were 'should', 'should not' and 'don't know'. Table 1 shows the distribution of opinion within the full sample. On three 
questions concerning the priesthood within the Church, British Catholics are generally very supportive of reforming existing teachings, with clear majorities in favour of allowing priests to get married (68\%), allowing married men to become priests (68\%), and enabling women to become priests (66\%). The level of opposition to these reforms ranges from 17 to $21 \%$, with similar proportions unsure (14-15\%). Attitudes vary more in relation to personal morality issues. While 55\% are supportive of recognising the marriages of same-sex couples, a much larger share is favourable towards allowing Catholics to use birth control (88\%). On the issue of who can receive communion, strong majorities support it being allowed for divorced Catholics who have remarried (67\%) and Catholics who are not married but are living together in a romantic relationship (76\%). Opposition to these propositions ranges from just $10 \%$ on the use of birth control to $29 \%$ being against the recognition of marriages between same-sex individuals. The proportion that was unsure also varied across questions, lowest at just $8 \%$ on birth control and highest at $16 \%$ for same-sex marriage and $17 \%$ on the issue of divorced and remarried Catholics being allowed communion.

An exploratory factor analysis of these seven items produced a two-factor solution, with dimensions which distinguished between the structural issues and social morality issues. All items that had high loadings (above 0.4) on the structural issues component had low loadings (below 0.4 ) on the social morality component and vice versa (full results are available on request). Based on these results, two dependent variables were constructed for the multivariate analysis, taking the form of summated scales. Firstly, a structural issues index based on three items (ranging from 0 to 6; Cronbach's Alpha $=0.76$ ). Secondly, a social morality issues index, based on four items (ranging from 0 to 8; Cronbach's Alpha=0.67). For each item, 'should' responses were coded as 2 , 'should not' responses were coded as 0 , and 'don't know' responses were coded as 1 . Higher values therefore indicate greater support for reforms within the Catholic Church. Gender roles are a pertinent area of analysis given that this is an area where the Catholic Church is viewed 'by Catholics and non-Catholics alike, to fall well short of modern expectations of gender equality' (Field 2014, p. 145); a finding replicated in the U.S. context, not least among Catholic women themselves (Gray and Gautier 2018).

The second set of questions concerned Catholics' views of which behaviours they perceive as sinful or not. Note that our questioning did not distinguish between different categories and/or severities of sin-e.g., 'mortal', 'venial'-within Catholic theology. In a British context, we doubt that such terms would be readily understood, except among a very small proportion of Catholics. Six of these questions focused on social morality issues, asking whether particular behaviours relating to relationships and reproduction were sinful or not (engaging in homosexual behaviour; being in a sexual relationship outside of marriage; the use of contraceptives; getting a divorce; having an abortion; getting remarried after a divorce without first getting an annulment). The other four, lying outside the scope of this article, focused on consumer or lifestyle behaviours: using non-renewable forms of energy; drinking alcohol; living in a house that is much larger than your family needs; spending money on luxuries without also giving to the poor. The response options were 'yes, it is a sin', 'no, it is not a sin', 'depends' and 'don't know'. 
Table 2 Distribution of opinion (\%)-Sinful moral behaviours

\begin{tabular}{llllc}
\hline Issue & Yes, it is a sin & $\begin{array}{l}\text { No, it is } \\
\text { not a sin }\end{array}$ & Depends & Don't know \\
\hline Engage in homosexual behaviour & 28 & 54 & 10 & 9 \\
Be in a sexual relationship outside of marriage & 30 & 51 & 14 & 6 \\
Use contraceptives & 11 & 74 & 10 & 5 \\
Get a divorce & 13 & 67 & 16 & 4 \\
Have an abortion & 29 & 42 & 24 & 5 \\
Get remarried after a divorce without first get- & 25 & 53 & 12 & 10 \\
ting an annulment & & & & \\
\hline
\end{tabular}

Percentages sum across each row but may not total 100 due to rounding

The distributions of opinion within the full sample for the social morality issues are shown in Table 2. Similar to the general pattern seen in Table 1, Catholics were generally supportive of reforms to Church teachings. Across questions, majorities or, in one case a plurality, of varying magnitudes took the view that these behaviours were not sinful. The plurality view was on abortion (42\%), the moral issue, that, as Hornsby-Smith observed, is perhaps the one 'to which official Catholicism is more strongly opposed' (1987, p. 162). The largest majority, 74\%, thought that contraception was not sinful (the issue with the highest level of support in the previous set of questions). Between these levels of support, around half thought that homosexual behaviour (54\%), being in a sexual relationship outside of marriage (51\%), and remarriage after a divorce without getting an annulment (53\%) were not sinful. Around two-thirds $(67 \%)$ took the view that divorce is not sinful. Across the questions, no more than three-in-ten said that any of the activities were sinful (highest for homosexual behaviour, obtaining an abortion, and remarriage without an annulment for divorce). The taking of a conditional position ('it depends') was highest on abortion (24\%) - an issue on which individuals can take a 'situationalist' approach, approving of it in some scenarios and disapproving in others (Jelen and Wilcox 2003) - and much lower on the other issues (10-16\%). The proportions unsure were relatively small across all of the issues, ranging between 4 and 10\%. Amongst Catholics in Britain, in aggregate terms, public opinion is very much in favour of liberal positions on social moral issues and of reforming access to the priesthood. Across Tables 1 and 2, there was no issue on which the plurality or majority view was consistent with the Church's social teachings.

An exploratory factor analysis (using Varimax rotation with PCA) of all ten items survey showed that they loaded onto two distinct dimensions (labelled as sinful moral behaviour and sinful consumer lifestyle behaviour). All items that had high loadings (above 0.4) on the sinful moral behaviour component had low loadings on the lifestyle sinful behaviours component, and vice versa. The exception was the use of contraceptives item, which had loadings of 0.58 on the first component and 0.41 on the second component. Given the disparity in the load values, this item was retained as part of the first component (full results are available on request). For the purposes of multivariate analysis, a summated scale was constructed based on these 
six items (Cronbach's Alpha $=0.81)$. For each item, 'no, it is not a sin' responses were coded as 2, 'yes, it is a sin' responses were coded as 0 , and 'it depends' or 'don't know' responses were coded as 1 . The summated scale ranges from 0 through to 12 , where higher values denote more agreement that these are not sinful behaviours.

\section{Independent Variables}

The analysis uses a wide range of variables to assess the factors associated with Catholics' attitudes towards the moral teachings of the Catholic Church. The independent variables encompass socio-demographic characteristics, religious socialisation, various aspects of personal engagement with faith, and party-political support.

\section{Socio-demographic Factors}

Gender and ethnic group (based on asking respondents which ethnic group they considered they belong to) are measured as dummy variables. Gender was coded as 1 for women and 0 for men, while ethnic group was measured as 1 for belonging to a white ethnic group and 0 for belonging to a mixed or non-white ethnic group. Generational differences are potentially consequential for British Catholics' attitudes, as has been seen in the U.S. Catholic Community (D'Antonio et al. 2001, 2007, 2013; Davidson et al. 1997; Mockabee 2007). As D'Antonio et al. note: 'Because each generation comes of age at a particular historical and sociocultural moment and embodies the spirit of that time and of those unique lived experiences, distinct generational habits tend to move with a particular generation as they age' (2013, p. 26). Building upon existing findings concerning the importance of generational differences, a series of dummy variables for generational groups were produced based on the classification scheme used by D'Antonio et al. (2013: Appendix), calibrated to the survey fieldwork year of 2019. This produces the following generational groups PreVatican: aged 79 and over (born up to 1940); Vatican II: aged 59-78 (1941-1960); Post-Vatican II: aged 40-58 (1961-1979); Millennial: aged 23-39 (1980-1996); Generation Z: aged 18 to 22 (born from 1997 onwards). As the Pre-Vatican group constituted a very small proportion of the overall survey sample (1.6\%; just 30 cases), it is omitted from the multivariate analysis. The Vatican II group was the omitted reference category. To differentiate between respondents living in (1) Scotland or (2) England and Wales, which are governed by separate national bishops' conferences, a dummy variable was used $(1=$ lives in Scotland; $0=$ lives in England or Wales). Educational attainment was measured as a dummy variable (1=university degree or higher level qualification; $0=$ lower level qualification or no formal qualification). Finally, a dummy variable was used to distinguish between those respondents in a valid marriage approved by the Catholic Church (scored as 1) and all other circumstances (in a marriage not approved as such or has some other relationship status-such as being in a relationship but not married, single, divorced, or widowed-scored as 0). 


\section{Religious Socialisation}

A dummy variable measures whether each respondent was raised from birth within the Catholic faith (scored as 1) or whether they converted at some stage (scored as $0)$. Dummy variables are used to capture the role of the Catholic Church in education at primary (ages 4 to 11) and secondary levels (ages 11 through to finishing mandatory schooling), as variation in schooling provision may affect the views of Catholics (D'Antonio et al. 2001, 2007, 2013). Moreover, Catholic schools in Britain have been an important part of the maintenance of the community's distinctive subculture, integral to religious socialisation and the transmission and reinforcement of communal identity and heritage (Hornsby-Smith 1987, p. 185). The sample was divided according to whether respondents only attended Catholic schools, experienced mixed provision (varying combinations of Catholic and non-Catholic schooling) or attended non-Catholic schools only. The group that solely attended Catholic schools forms the omitted reference category.

\section{Religious Beliefs}

A dummy variable captured whether respondents expressed a firm belief in God (scored as 1) or whether they expressed a more qualified or contingent belief or did not believe in God at all (0). A composite religious belief index, based on the following items: life after death; heaven; hell; purgatory; real presence of Christ's body and blood in the Eucharist; religious miracles; and the intercessory powers of the Saints. Responses expressing belief were scored as 2, do not know responses were scored as 1 , and responses indicating a lack of belief were scored as 0 . Higher scores indicate greater levels of belief.

\section{Religious Behaviour}

Respondents were asked how frequently they attended Mass and how frequently they prayed. Both variables ranged from 0 to 8 , with higher values denoting more frequent attendance. These measures tap into different indicators of religious commitment: church attendance measures 'ritualistic behaviour' and prayer gauges 'private devotionalism'. These are well-established measures used to study the social attitudes of religious traditions in general (Guth and Green 1993) and Catholics in particular (Mockabee 2007).

\section{Religious Salience}

Two measures are used to capture the personal importance of religion in general and of the Catholic Church in particular. First, self-rated religiosity is measured on a scale from 0 to 10 , where higher values denote feeling more religious. This also forms an indicator of religious commitment used in existing research, although here it is a more general measure of the salience of religion rather than directly gauging to what extent faith provides guidance for how an individual lives their life (Guth and Green 1993). Second, a question asking how important 
the Catholic Church is personally — which has been used, on a long-running basis, as one indicator of an individual's commitment to the Catholic Church in the U.S. (D'Antonio et al. 2013, 2007, 2001). This variable ranges from 1 through to 5, where higher values indicate greater personal importance of the Catholic Church.

\section{Religion and Social Life}

Two variables are used to measure involvement in parish life and social integration with other Catholics. First, a dummy variable measuring whether a respondent has served in any of a variety of roles in their local church or parish in the last twelve months ( 1 if yes, 0 if no). Second, a variable capturing how many of their five closest friends are Catholic (ranging from none through to five). Accounting for religious involvement and social interaction is important as, through these channels, Catholics could receive cues and partake in discussions that guide and reinforce conformity to the official teachings of the Church.

\section{Party Political Affiliation}

Research has shown that the party-political affiliations and ideological leanings of Catholics can be consequential for their attitudes. In the U.S., on social morality issues (Mulligan 2006; Smith 2005; Perl and McClintock 2001; Jelen 2005; Bjarnason and Welch 2004) and on issues of moral authority within the Church (Pew Research Center 2015; D’Antonio et al. 2013). In Britain, for Catholics' views on abortion (Clements 2014a). The survey did not feature a question on which party an individual identified with, so the measure of party support is based on respondents' voting intention if a general election were to be held. This is operationalised as a series of dummy variables for Conservative, Labour, Liberal Democrats, other party, and would not vote or are unsure. Conservative Party supporters are the omitted reference category.

\section{Results and Discussion}

The results show the net impact of socio-demographic factors, religious socialisation, religious commitment, and party-political affiliation on for three sets of issues. A reminder that the dependent variables were constructed so that higher values indicate positions that are generally inconsistent with or opposed to, the teachings and moral authority of the Catholic Church. The results from the linear (OLS) regression analyses of British Catholics' attitudes towards structural issues are presented in Table 3 (access to the priesthood) and moral issues in Table 3 (personal morality) and Table 4 (sinful behaviours). The results from the structural and moral issues are discussed in turn. 


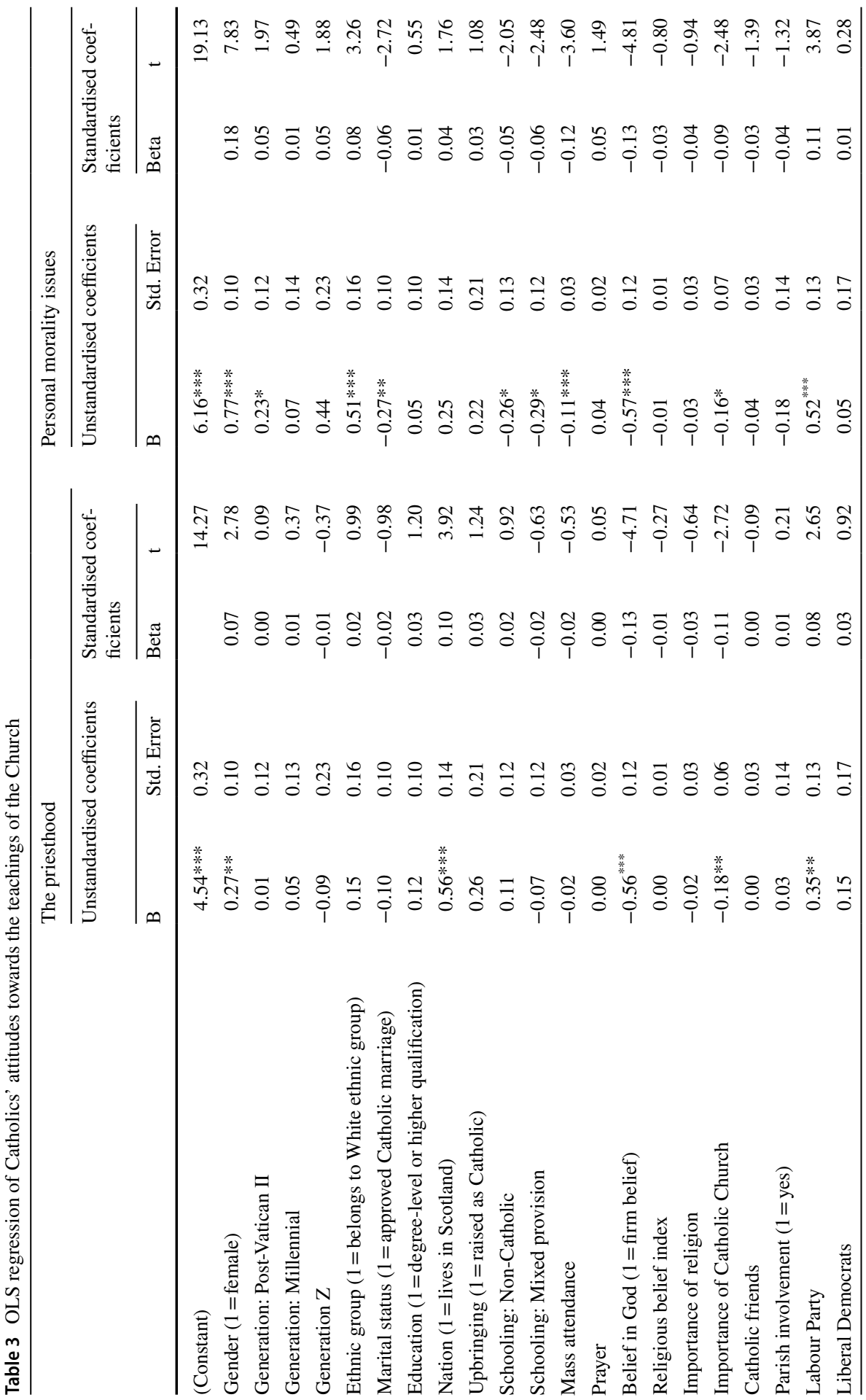




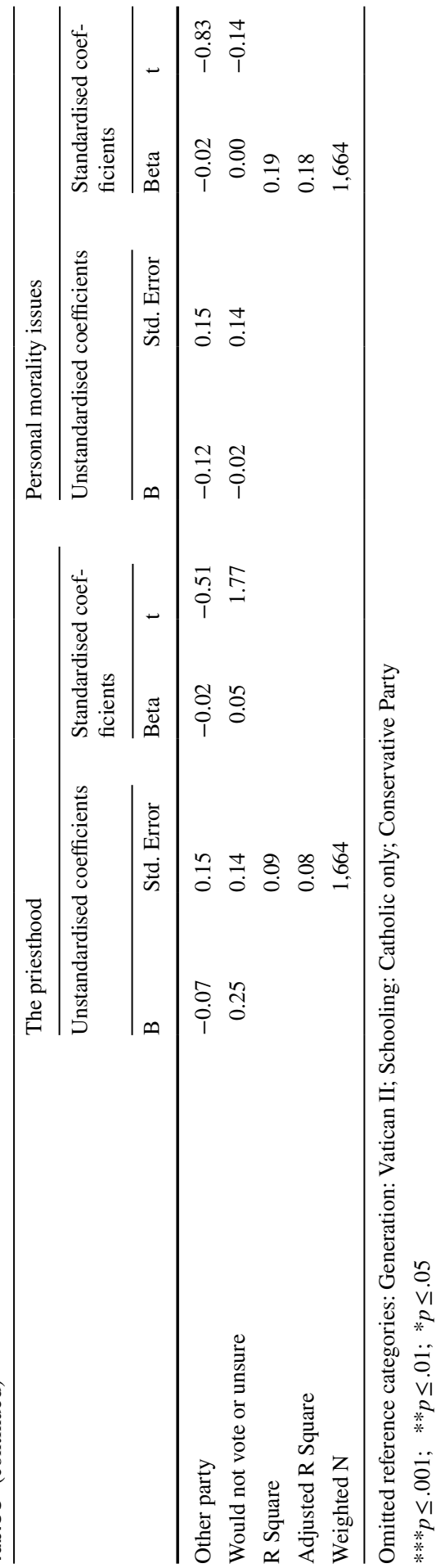


Table 4 OLS regression of Catholics' attitudes towards sinful moral behaviours

\begin{tabular}{|c|c|c|c|c|}
\hline & \multicolumn{2}{|c|}{ Unstandardised coefficients } & \multicolumn{2}{|c|}{$\begin{array}{l}\text { Standardised } \\
\text { coefficients }\end{array}$} \\
\hline & B & Std. Error & Beta & $\mathrm{t}$ \\
\hline (Constant) & $10.55^{* * *}$ & 0.49 & & 21.7 \\
\hline Gender $(1=$ female $)$ & $0.85^{* * *}$ & 0.15 & 0.12 & 5.68 \\
\hline Generation: Post-Vatican II & $0.97^{* * *}$ & 0.18 & 0.13 & 5.43 \\
\hline Generation: Millennial & 0.36 & 0.21 & 0.05 & 1.74 \\
\hline Generation Z & $1.07^{* *}$ & 0.35 & 0.07 & 3.04 \\
\hline Ethnic group ( 1 = belongs to White ethnic group) & 0.12 & 0.24 & 0.01 & 0.52 \\
\hline Marital status $(1=$ approved Catholic marriage $)$ & $-0.43^{* *}$ & 0.15 & -0.06 & -2.81 \\
\hline Education ( $1=$ degree-level or higher qualification) & 0.24 & 0.15 & 0.04 & 1.63 \\
\hline Nation $(1=$ lives in Scotland $)$ & -0.09 & 0.22 & -0.01 & -0.44 \\
\hline Upbringing ( $1=$ raised as Catholic) & 0.37 & 0.31 & 0.03 & 1.17 \\
\hline Schooling-non-Catholic & -0.03 & 0.19 & 0.00 & -0.17 \\
\hline Schooling-mixed provision & -0.22 & 0.18 & -0.03 & -1.24 \\
\hline Mass attendance & $-0.13 * *$ & 0.05 & -0.09 & -2.72 \\
\hline Prayer & -0.01 & 0.04 & -0.01 & -0.36 \\
\hline Belief in God ( $1=$ firm belief $)$ & $-0.66 * * *$ & 0.18 & -0.09 & -3.67 \\
\hline Religious belief index & $-0.11 * * *$ & 0.02 & -0.15 & -5.33 \\
\hline Importance of religion & $-0.15^{* * *}$ & 0.04 & -0.13 & -3.70 \\
\hline Importance of Catholic Church & $-0.47 * * *$ & 0.10 & -0.16 & -4.78 \\
\hline Catholic friends & $-0.09 *$ & 0.04 & -0.05 & -2.15 \\
\hline Parish involvement ( $1=$ yes $)$ & -0.37 & 0.21 & -0.04 & -1.76 \\
\hline Labour Party & 0.36 & 0.20 & 0.05 & 1.78 \\
\hline Liberal Democrats & 0.20 & 0.26 & 0.02 & 0.78 \\
\hline Other party & 0.38 & 0.22 & 0.04 & 1.70 \\
\hline Would not vote or unsure & 0.05 & 0.21 & 0.01 & 0.22 \\
\hline R Square & & 0.34 & & \\
\hline Adjusted R Square & & 0.33 & & \\
\hline Weighted N & & 1,664 & & \\
\hline
\end{tabular}

Omitted reference categories: Generation: Vatican II; Schooling: Catholic only; Conservative Party ${ }^{* * *} p \leq .001 ; * * p \leq .01 ; * p \leq .05$

\section{Structural Issues}

The results in Table 3 show that, in terms of Catholics' views on access to the priesthood (a key debate relating to structural issues within the Church), women are more likely than men to agree that the Catholic Church should make reforms in this area. Perhaps surprisingly, there are no significant differences between the Vatican II grouping (the omitted reference category and the oldest generation considered here) and the younger generations on these structural issues. Net of the effect of other independent variables, then, there are no significant differences based on 
generational group. Similarly, there are no significant differences on priesthood issues based on ethnic group, marital status, or educational attainment. Whether a respondent lives in Scotland or in England and Wales-governed by separate bishops' conferences-does have an impact, with those living in Scotland being more supportive of reforming access to the priesthood. Aspects of Catholics' religious socialisation do not have an impact, both in terms of upbringing and their experience of schooling (experience of mixed or non-Catholic provision compared to having only attended Catholic schools).

In a limited way, religious commitment affects how Catholics in Britain view the merits of reforming the priesthood. Those Catholics with a firm belief in God are less likely to support reforms than those who are less sure or do not believe in God, but the general religious belief index does not have a statistically significant impact. Those for whom the Catholic Church is an important part of their lives are less likely to be supportive of reforms to the norms governing the priesthood, but this is not the case for the more general measure or the salience of religion. Both of the behavioural indicators of religious commitment-frequency of attendance at Mass and regularity of prayer-are not significantly related to views on the priesthood within the Catholic Church. Also, views on the reform of access to the priesthood are not affected by Catholics' wider social involvement in their faith, both in terms of having held a voluntary role at the local level and the extent of their close friends being Catholic. Net of the impact of socio-demographic factors and religious commitment, party support does affect views on internal reforms to the Church, with Labour Party voters being more approving of reform than Conservative Party supporters.

\section{Moral Issues}

The results for social-moral issues presented in Table 3 (concerning relationships and reproduction) show that, again, attitudes differ based on gender: women are more likely to hold liberal views on these issues than men are, confirming similar findings from other research into the views of Catholics in Britain (Clements 2014a, b). To use the term of D'Antonio et al. (2007), gender is a key 'demographic prior' shaping Catholics' views in Britain. Based on generational group, only Generation X Catholics are more likely to hold liberal views compared to the Vatican II generation (the eldest under consideration here). Those in the younger groups-Generation $\mathrm{Z}$ and Millennials-are not significantly different in their views compared to Vatican II Catholics. Some of the demographic characteristics that had no impact on Catholics' views on structural issues are associated with their attitudes on morality issues. Those Catholics within an approved marriage are less likely to have liberal stances on these issues. Those belonging to a White ethnic group are more supportive than those belonging to a minority ethnic group. Research in the U.S. have shown differences of view on abortion and same-sex marriage between White and Hispanic Catholics, with the latter groups holding more socially conservative views (Pew Research Center 2008). The effects of schooling, potentially a key formative influence on how Catholics develop their engagement with faith, are evident here. However, the results show 
that those who attended mixed provision or had no formal Catholic schooling are less supportive of reforms than those who experienced solely Catholic schooling at primary and secondary level.

Unlike in relation to structural issues concerning access to the priesthood, Mass attendance has a clear impact here. Those Catholics who frequently attend Mass are less likely to support liberal positions on morality issues. But attitudes on these issues are not significantly affected by regularity of prayer. Other indicators of religious commitment also have effects in a similar direction. Having a firm belief in God and having the Catholic Church play a more salient role in one's life are both negatively related to liberal views on morality issues. As before, this is not the case for the composite religious belief index and the general salience of religion in Catholics' lives. There are no significant effects based on local involvement with the Catholic Church and the extent to which one's close friends share the same religion. Based on party support, Labour supporters hold more liberal views on these issues compared to Conservative supporters, as was the case for structural reforms concerning the priesthood.

Table 4 shows that a wider plurality of factors underpin Catholics' views of what behaviours are sinful or not. Gender is yet again clear differentiator of attitudes within the Catholic community in Britain, with women more likely than men to take the view that these are not sinful moral behaviours. There are clear generational differences: those in Generation $\mathrm{Z}$ and Generation X, though not Millennials, are more likely to see these behaviours as not sinful, compared to the Vatican II generation. On the structural and moral issues examined here (as shown in Tables 3,4), Millennial Catholics have not held views that clearly differ from those held by Vatican II Catholics once other independent variables are taken into account. Those in approved Catholics marriages again are less likely to see these behaviours as not being sinful. There are no significant effects for educational attainment, ethnic identification, or religious socialisation of Catholics, based on their upbringing and schooling.

Religious commitment factors as a whole-manifested as behaving, believing and salience-play a stronger role in underpinning British Catholics' views on what constitutes sinful behaviour. Here, the sole indicator of commitment that is not statistically significant is frequency of prayer, as was also the case for the other issue types. For the other indicators, the effects are consistent-that is, more religiouslycommitted are Catholics are always less likely to disagree that these behaviours are not sinful. Earlier research amongst Catholic parishioners in the U.S. found that religious commitment was one of the most important pathways promoting agreement with the Catholic Church's sexual and reproductive norms (Davidson et al. 1997, pp. 246-247). These results reiterate the importance of using a multi-faceted approach to measuring religiosity amongst Catholics, showing that while Mass attendance is often a fertile variable for differentiating moral attitudes, as it is here, it has to be considered in conjunction with other indicators. Having a greater number of Catholic friends is negatively related to thinking that these behaviours are not sinful, while there are no significant effects for having held a voluntary role in the Church or for party-political affiliations, the latter a clear contrast to the results seen for the other OLS models in Tables 3, 4. 


\section{Overall}

Taken together, the findings show that socio-demographic factors and religious commitment underpin British Catholics' views on social moral and structural issues. Three broader reflections are worth noting here. First, gender seems to be an important and consistent dividing line amongst the Catholic community in Britain, on moral and structural issues-a particularly instructive finding given that other research has found that Catholic women have been more liberal on moral issues (Clements 2014a, b). Second, the results did not show the younger generations of Catholics consistently taking positions that stood apart from their elders. In fact, across moral issues, members of the Post-Vatican II generation (aged 40-58 in the sample) were more likely to take positions contrary to the teachings of the Catholic Church, compared to those in the Vatican II generation (aged 59-78). This is interesting in the context of research into U.S. Catholics showing that age-related differences were not consistent across moral issues (Pew Research Center 2015, pp. 104-05, 112-13). These findings build on other recent research into age-related variation in attitudes amongst British Catholics (Woodhead 2013a, b; Bullivant and Clements 2020). While they show that the generational picture in contemporary Britain is a more variegated one than that found in earlier research into the Catholic Community in England: 'Catholics are more likely to be critical of the institutional Church or of its authorities or of its official teachings or regulations the younger they are' (Hornsby-Smith and Lee 1979, pp. 130-131). Third, adopting a multi-faceted approach to religious engagement tailored to the Catholic faith, expressed as beliefs, behaviour and salience, greater religious commitment manifested in these different ways consistently decreased the likelihood that British Catholics would take positions that dissent from the teachings of the Church. The direction of the association was clear and uniform across the different issues examined in this study, but the particular types of religious commitment in play differed.

\section{Limitations}

There are several imitations to this study which should be acknowledged while also signposting where future research could usefully focus. First, while this study provided in-depth analysis of attitudes on Church teachings, a limitation is that questions specifically probing the appropriate locus of moral authority amongst British Catholics were not available. This is something worth pursuing in future research, to see whether and how British Catholics' views on the appropriate focus of decision-making - solely on the basis of clerical authority, jointly between bishops and the laity, or by individuals relying on their consciencesvary across different issues (D'Antonio et al. 2013). Second, this study did not examine whether and how differing views on social moral and structural issues are themselves consequential for British Catholics' attitudes concerning other areas of their faith. As D'Antonio et al. note: 
Catholics' views about church authority and religious authority affect many other areas of their lives. Those who believe in the official doctrines and teachings of the magisterium will have in life commitments much different from those of others who do not, or who see church teachings as no more than one option among many (1996, p. 41).

Third, this study only used quantitative research methods and so there is clearly an opportunity for researchers to utilise qualitative methods, such as in-depth interviews or focus groups, to gain more insight into the experiences and motivations of Catholics in Britain (or from within specific demographic groups in the wider community). This would provide richer findings in terms of Catholics' lived experience of their faith, how they relate to the institutional Church at the national and local levels, and the reasoning behind their positions on the key moral and structural issues analysed here (cf. Baggett 2008; Noelle Pratt 2014).

\section{Conclusions and Implications}

This study has provided important insights into the contemporary sources of attitudinal heterogeneity amongst Catholics (in Britain), focusing on explaining variations in opinion on both social moral and structural issues within the Church. As a whole, Catholics in Britain are often in favour of liberal positions on social moral issues and of reforming access to the priesthood. In fact, on no single issue was the modal viewpoint consistent with the Church's moral teachings. This provides further evidence, in contemporary Britain, of the continuation of the trends noted by Hornsby-Smith: that of Catholics' increasing contestation of and decoupling from clerical authority on issues of morality and of their broader attitudinal convergence with wider society (on the specific issue of contraception, see Harris 2018; Geiringer 2019). Moreover, in analysing in depth the sources of heterogeneity in Catholics' attitudes on these issues, which are at the core of debates within the Catholic Church, significant dividing lines emerged based on gender and religious commitment, though generational fault-lines between young and old were not consistently in evidence.

This latter point relates to another big-picture trend within British religion as a whole: the steady growth over several decades in those identifying as having no religion (Lee 2015). These now account for over half of the adult population (Voas and Bruce 2019), fuelled largely by a growing willingness of those brought up with a religion to identify as nones later in life. According to pooled 2012-2016 BSA data, for example, only $56 \%$ of those who said they were brought up Catholic now still identified as such, with over a third of all such 'cradle Catholics' now describing their current affiliation as 'no religion'. There was, moreover, a clear generational effect in evidence: while $20 \%$ of those born between 1925 and 1944 were now nones, fully $48 \%$ of those born between 1985 and 1998 were nones. This has important implications for understanding the intergenerational dynamics within the (still) self-identifying Catholic population. The greater propensity of younger Catholics to disaffiliate (itself evidence of the continued waning of 'cultural' or 'customary' 
forms of Catholic belonging; cf. Hornsby-Smith 2004) means that the more weakly committed remove themselves from the overall pool of self-identifying Catholics, leaving behind the more committed 'remnant'. This should, in itself, produce a kind of survivorship bias effect ${ }^{1}$ in cross-generational data on British Catholics (as indeed, on British religion as a whole; see Wilkins-Laflamme 2016). It also means that those younger Catholics who do still see themselves as Catholics must 'own it' - since they are, and know they are, swimming against the tide in persisting as Catholics-far more so than was necessary for cradle Catholics of their parents' or grandparents' generations. This should, in itself, produce a kind of minority effect among younger Catholics, especially where they are closely networked with other young Catholics (for example, within Catholic university chaplaincies or youth movements), further encouraging them to double down and embrace their Catholic counter(sub)culturalism. However, further research is needed to determine if these two effects are in force, and if so, in which proportions, and how significant they are. Given rising levels of such 'nonversion' (Bullivant 2017; Thiessen and WilkinsLaflamme 2020)-i.e., the phenomenon of those brought up in a religion coming to identify as 'nones' later in life - in many countries, these are issues which many other researchers utilizing survey data on religion will need to face up to, think about, and account for in their own analyses.

While this study confines itself to British Catholicism, these findings suggest a number of implications that go beyond this geographical focus, including for the U.S. Sociologists of religion have, with good reason, historically viewed Britain and the U.S. as contrasts-with vigorous debates over which counts as 'the exceptional case' to the proper socio-religious ordering of things (e.g., Davie 2002; Greeley 2004, pp. 197-214; Berger et al. 2008). This ought not to obscure, however, a significant commonality: linguistically and culturally, for instance, Britain has far more in common with the U.S. than it does with the rest of Europe; and the U.S. is in many ways much 'nearer' to Britain than to most its nearest neighbours (Canada excepted). Furthermore, rising numbers of nones (Thiessen and LaFlamme 2020; Bullivant, forthcoming), a severely declined Protestant mainline (Lantzer 2012), and growing non-Christian religious diversity (Eck 2001), are all direct points of contact between the two socio-religious contexts. Within Catholicism specifically, one might also highlight a waning Irish Catholic culture spurring decline in former heartlands, significant sexual abuse scandals, ongoing injections of vitality from immigrants from a range of countries, and growing levels of both lapsation and disaffiliation in both countries (Bullivant 2019). While it would be naïve to view the British data on moral and social attitudes as constituting a quasi-Dickensian 'ghost of Catholic future', this study nevertheless contends that at least some of the same underlying dynamics are restructuring both American religion as a whole, and Catholic pastoral life in particular.

\footnotetext{
1 A term we borrow here from the business and economic literature to refer to a particular type of selection bias that inflates the presence of relative 'winners' in data on company or stock performance, since the failures go under and thus remove themselves (Brown et al. 1992).
} 
Open Access This article is licensed under a Creative Commons Attribution 4.0 International License, which permits use, sharing, adaptation, distribution and reproduction in any medium or format, as long as you give appropriate credit to the original author(s) and the source, provide a link to the Creative Commons licence, and indicate if changes were made. The images or other third party material in this article are included in the article's Creative Commons licence, unless indicated otherwise in a credit line to the material. If material is not included in the article's Creative Commons licence and your intended use is not permitted by statutory regulation or exceeds the permitted use, you will need to obtain permission directly from the copyright holder. To view a copy of this licence, visit http://creativecommons.org/licen ses/by/4.0/.

\section{References}

Baggett, Jerome P. 2008. Sense of the Faithful: How American Catholics Live Their Faith. New York: Oxford University Press.

Barclay, Andrew, Maria Sobolewska, and Robert Ford. 2019. Political realignment of British Jews: Testing competing explanations. Electoral Studies 61: 1-16.

Berger, Peter, Grace Davie, and Effie Fokas. 2008. Religious America, Secular Europe? A Theme and Variations. Aldershot: Ashgate.

Berrelleza, Erick, and Phyllis Zagano. 2019. What Do U.S. Catholics Think About Women Deacons? Review of Religious Research 61: 273-284.

Bjarnason, Thoroddur, and Michael R. Welch. 2004. Father Knows Best: Parishes, Priests, and American Catholic Parishioners' Attitudes Toward Capital Punishment. Journal for the Scientific Study of Religion 43: 103-118.

Brown, Stephen J., William Goetzmann, Roger G. Ibbotson, and Stephen A. Ross. 1992. Survivorship Bias in Performance Studies. Review of Financial Studies 5: 553-580.

Bruce, Steve. 2012. Religion and Politics in the United Kingdom. London: Routledge.

Bullivant, Stephen. 2016a. Contemporary Catholicism in England and Wales: A Statistical Summary Based on Recent British Social Attitudes Data. Twickenham: Benedict XVI Centre for Religion and Society. http://www.stmarys.ac.uk/benedict-xvi/contemporary-catholicism.htm.

Bullivant, Stephen. 2016b. Catholic Disaffiliation in Britain: A Quantitative Overview. Journal of Contemporary Religion 31: 181-197.

Bullivant, Stephen. 2017. The "No Religion" Population of Britain: Recent Data from the British Social Attitudes Survey (2015) and the European Social Survey (2014). Twickenham: Benedict XVI Centre for Religion and Society. https://www.stmarys.ac.uk/research/centres/benedict-xvi/no-religionpopulation.aspx

Bullivant, Stephen. 2019. Mass Exodus: Catholic Disaffliation in Britain and America since Vatican II. Oxford: Oxford University Press.

Bullivant, Stephen. Forthcoming. Nonverts: The Making of Ex-Christian America(ns). New York: Oxford University Press.

Bullivant, Stephen and Ben Clements. 2020. Everybody Loves Francis? British Catholics' 'Job Approval' Ratings of the Pope. University of Leicester and Benedict XVI Centre for Religion and Society. https://catholicsinbritain.le.ac.uk/wp-content/uploads/2020/03/Benedict-Centre_Pope-FrancisReport.pdf.

Clements, Ben. 2014a. An assessment of long-term and contemporary attitudes towards "sanctity of life" issues amongst Roman Catholics in Britain. Journal of Religion in Europe 7: 269-300.

Clements, Ben. 2014b. Assessing the determinants of the contemporary social attitudes of Roman Catholics in Britain: Abortion and homosexuality'. Journal of Contemporary Religion 29: 491-501.

Clements, Ben. 2015. Religion and Public Opinion in Britain: Continuity and Change. Basingstoke: Palgrave Macmillan.

Clements, Ben. 2016a. Weekly churchgoing amongst Roman Catholics in Britain: Long-term trends and contemporary analysis. Journal of Beliefs and Values 38: 32-44.

Clements, Ben. 2016b. Surveying Christian Beliefs and Religious Debates in Post-War Britain. Basingstoke: Palgrave Macmillan. 
Clements, Ben. 2017. Catholic voters in Britain: what are their political preferences? LSE British Politics \& Policy. https://blogs.lse.ac.uk/politicsandpolicy/catholic-voters-in-britain-what-are-their-politicalpreferences/.

Clements, Ben. 2020. Catholics and church attendance in Britain. Catholics in Britain project. https:// catholicsinbritain.le.ac.uk/resources/catholics-and-church-attendance-in-britain/\#.YE88X537Q2w.

D'Antonio, William V. 2017. US Catholics weigh in on 2016 election in new survey. National Catholic Reporter, November 1st. https://www.ncronline.org/news/politics/us-catholics-weigh-2016-elect ion-new-survey.

D’Antonio, William V., James D. Davidson, Dean R. Hoge, and Ruth A. Wallace. 1989. American Catholic Laity in a Changing Church. Kansas City, MO: Sheed \& Ward.

D’Antonio, William V., James D. Davidson, Dean R. Hoge, and Ruth A. Wallace. 1996. Laity, American and Catholic: Transforming the Church. Kansas City, MO: Sheed \& Ward.

D’Antonio, William V., James D. Davidson, Dean R. Hoge, Katherine Meyer, William B. Bishop, and Friend. 2001. American Catholics: Gender, Generation, and Commitment. Lanham, MD: Rowman $\&$ Littlefield.

D’Antonio, William V., James D. Davidson, Dean R. Hoge, and Mary L. Gautier. 2007. American Catholics Today: New Realities of Their Faith and Their Church. Lanham, Md.: Rowman \& Littlefield.

D’Antonio, William V., James D. Davidson, Dean R. Hoge, and Mary L. Gautier. 2011. American Catholics and Church Authority. In The Crisis of Authority in Catholic Modernity, eds Michael J. Lacey and Francis Oakley, 273-92. New York Oxford University Press.

D’Antonio, William V., Michele Dillon, and Mary L. Gautier. 2013. American Catholics in Transition: Persisting and Changing. Lanham: Rowman \& Littlefield.

Davie, Grace. 2002. Europe: The Exceptional Case: Parameters of Faith and Society in the Modern World. London: Darton, Longman and Todd.

Davidson, James, Andrea S. Williams, Richard A. Lamanna, Jan Stenftenagel, Kathleen Maas Weigart, Wiliam J. Whalen, and Patricia Wittberg. 1997. The Search for Common Ground: What United and Divides Catholic Americans. Huntington, Ind: Our Sunday Visitor Publishing Division.

Eck, Diane L. 2001. A New Religious America: How a "Christian Country" Has Become the World's Most Religiously Diverse Nation. San Francisco, CA: HarperOne.

Field, Clive D. 2014. Another Window on British Secularization: Public Attitudes to Church and Clergy Since the 1960s. Contemporary British History 28: 190-218.

Geiringer, David. 2019. The Pope and the Pill: Sex, Catholicism and Women in Post-War England. Manchester: Manchester University Press.

Gray, Mark M. and Mary L. Gautier. 2018. Catholic Women in the United States: Beliefs, Practices, Experiences, and Attitudes. Washington, D.C.: Center for Applied Research in the Apostolate and America. https://cara.georgetown.edu/CatholicWomenStudy.pdf. Accessed 18 August 2020.

Greeley, Andrew M. 1990. The Catholic Myth: The Behavior and Beliefs of American Catholics. New York: Charles Scribner's Sons.

Greeley, Andrew. 2004. Religion in Europe at the End of the Second Millennium: A Sociological Profile. New Brunswick, NJ: Transaction.

Guth, James L. and John C. Green. 1993. Salience: The Core Concept. In D (eds), Rediscovering the Religious Factor in American Politics, eds David C. Leege and Lyman A. Kellstedt, 157-74. Armonk, N.Y.: M. E. Sharpe.

Harris, Alana. 2018. "A Galileo-Crisis Not a Luther-Crisis"? English Catholics' Attitudes to Contraception. In The Schism of '68: Catholicism, Contraception and 'Humanae Vitae' in Europe, 19451975, ed. Alana Harris, 73-96. Basingstoke: Palgrave Macmillan.

Hornsby-Smith, Michael P. 1987. Roman Catholics in England: Studies in Social Structure Since the Second World War. Cambridge: Cambridge University Press.

Hornsby-Smith, Michael P., ed. 1991. Roman Catholic beliefs in England. Cambridge: Cambridge University Press.

Hornsby-Smith, Michael P. 1999. Catholics in England 1950-2000: Historical and Sociological Perspectives. London: Cassell.

Hornsby-Smith, Michael P. 2004. The Changing Identity of Catholics in England. In Religion, Identity and Change: Perspectives on Global Transformations, ed. Simon Coleman and Peter Collins, 42-56. Abingdon: Routledge.

Hornsby-Smith, Michael P., and Kathryn A. Turcan. 1981. Are Northern Catholics different?'. Clergy Review 66: 231-241.

Hornsby-Smith, Michael P., Raymond M. Lee, and Kathryn A. Turcan. 1982. A typology of English Catholics. Sociological Review 30: 433-459. 
Hornsby-Smith, Michael P., and Raymond M. Lee. 1979. Roman Catholic Opinion: A Study of Roman Catholics in England and Wales in the 1970s. Guildford: University of Surrey.

Jelen, Ted G., and Clyde Wilcox. 2003. Causes and Consequences of Public Attitudes Toward Abortion: A Review and Research Agenda. Political Research Quarterly, 56: 489-500.

Jelen, Ted G. 2005. American Catholics and the Structure of Life Attitudes. University of St. Thomas Law Journal 2: 397-420.

Kinnear, Tim. Forthcoming. Statistical Appendices. In The Oxford History of British and Irish Catholicism, vol. 5, ed Alana Harris. Oxford: Oxford University Press.

Knoll, Benjamin R., and Cammie Jo Bolin. 2018. She Preached the Word: Women's Ordination in Modern America. Oxford: Oxford University Press.

Lantzer, Jason S. 2012. Mainline Christianity: The Past and Future of America's Majority Faith. New York: New York University Press.

Lee, Lois. 2015. Recognizing the Non-religious: Reimagining the Secular. Oxford: Oxford University Press.

Mockabee, Stephen. 2007. The political behavior of American Catholics: change and continuity. In: From Pews to Polling Places: Faith and Politics in the American Religious Mosaic, ed. J. Matthew Wilson, 81-104. Washington, DC: Georgetown University Press.

Mockabee, Stephen T., Joseph Quin Monson, and J. Tobin Grant. 2001. Measuring Religious Commitment Among Catholics and Protestants: A New Approach. Journal for the Scientific Study of Religion 40: 675-690.

Mulligan, Kenneth. 2006. Pope John Paul II and Catholic Opinion towards the Death Penalty and Abortion. Social Science Quarterly 87: 740-753.

Newman, John H. 1875. A Letter Addressed to His Grace the Duke of Norfolk, on Occasion of Mr. Gladstone's Recent Expostulation. New York: Catholic Publication Society.

Perl, Paul, and Jamie S. McClintock. 2001. The Catholic "Consistent Life Ethic" and Attitudes Toward Capital Punishment and Welfare Reform. Sociology of Religion 62: 275-299.

Pew Research Center. 2008. A Portrait of American Catholics on the Eve of Pope Benedict's Visit to the U.S. https://www.pewforum.org/2008/03/27/a-portrait-of-american-catholics-on-the-eve-of-popebenedicts-visit-to-the-us/.

Pew Research Center. 2015. Survey of U.S. Catholics and Family Life. https://www.pewforum.org/2015/ 09/02/u-s-catholics-open-to-non-traditional-families/.

Populus. 2010. The Times poll. 10-12 September 2010. http://populuslimited.com/uploads/download_ pdf-120910-The-Times-The-times-Poll---September-2010.pdf.

Pratt, Noelle Tia. 2014. Catholic Young Adults' Attitudes Toward the Church's Pro-Life Teachings: A Bellwether for the Church's Political Strategy? Interdisciplinary Journal of Research on Religion 10: $1-22$.

Rinaman, William C., Matthew T. Loveland, Robert F. Kelly, and William R. Barnett. 2009. Dimensions of Religiosity among American Catholics: Measurement and Validation. Review of Religious Research 50: 413-444.

Smith, Gregory A. 2005. The Influence of Priests on the Political Attitudes of Roman Catholics. Journal for the Scientific Study of Religion 44: 291-306.

Smith, Christian, Kyle Longest, Jonathan Hill, and Kari Christoffersen. 2014. Young Catholic America: Emerging Adults In, Out of, and Gone from the Church. Oxford: Oxford University Press.

Thiessen, Joel, and Sarah Wilkins-Laflamme. 2020. None of the Above: Nonreligious Identity in the US and Canada. New York: New York University Press.

Voas, David, and Steve Bruce. 2019. Religion. In British Social Attitudes: The 36th Report, ed. J. Curtice, E. Clery, J. Perry, M. Phillips, and N. Rahi, 17-38. London: National Centre for Social Research.

Wald, Kenneth D., and Corwin E. Smidt. 1993. Measurement Strategies in the Study of Religion and Politics. In Rediscovering the Religious Factor in American Politics, ed. David C. Leege and Lyman A. Kellstedt, 26-49. Armonk, N.Y.: M. E. Sharpe.

Wilkins-Laflamme, Sarah. 2016. The remaining core: a fresh look at religiosity trends in Great Britain. British Journal of Sociology, 67: 632-54.

Woodhead, Linda. 2013a. What we really think. The Tablet, $9^{\text {th }}$ November. https://www.thetablet.co.uk/ features/2/771/what-we-really-think.

Woodhead, Linda 2013b. Endangered species. The Tablet, $16^{\text {th }}$ November. https://www.thetablet.co.uk/ features/2/826/endangered-species. 
YouGov. 2015. YouGov / The Tablet Survey Results. 30 March - 1 April 2015. https://d25d2506sfb94s. cloudfront.net/cumulus_uploads/document/ktmkf5g7qy/TheTablet_Results_150401_religious_ leaders_Website.pdf.

Publisher's Note Springer Nature remains neutral with regard to jurisdictional claims in published maps and institutional affiliations.

\section{Authors and Affiliations}

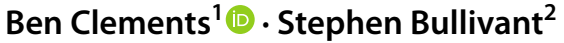

Ben Clements

bc101@leicester.ac.uk

1 School of History, Politics and International Relations, University of Leicester, Leicester LE1 7RH, UK

2 Benedict XVI Centre for Religion and Society, St Mary's University, London TW1 4SX, UK 